\title{
ARE FOREIGN AID AND ECONOMIC GROWTH POSITIVELY RELATED? EMPIRICAL EVIDENCE FROM BANGLADESH
}

\author{
Shahadat Hussain \\ Assistant Professor \\ Department of Finance and Banking \\ University of Barishal, Barishal, Bangladesh \\ E-mail: shahadathussain09@ gmail.com \\ (iD https://orcid.org/0000-0003-0794-4277 \\ Md. Habibur Rahman \\ Assistant Professor \\ Department of Finance and Banking \\ Jatiya Kabi Kazi Nazrul Islam University \\ Trishal, Mymensingh-2224, Bangladesh \\ E-mail: habiburfbjkkniu@gmail.com \\ Dhttps://orcid.org/0000-0001-9763-6619
}

Received: December 08, 2021

Accepted: January 31, 2022 Online Published: February 13, 2022

DOI: 10.46281/bjmsr.v5i1.1611

URL: https://doi.org/10.46281/bjmsr.v5i1.1611

\begin{abstract}
As an emerging country, the progress of Bangladesh is highly promising. Foreign aid may be one of the key players fueling such advancement. The note is an attempt to examine the effect of foreign aid on the economic growth of Bangladesh. With a view to fulfill our objective, the study employs annual time series data during the period of 1971 to 2019. It has used some econometric tools i.e., Unit Root Tests and OLS Methods to process the collected data. The dependent variable is Gross Domestic Product (GDP) while other independent variables i.e., Foreign Aid (ODA), Gross Capital Formation (GCF), Population (POP), and Education (EDU). The test results confirmed that GDP growth is positively related to foreign aid, gross capital formation, and education, but negatively related to population. In Bangladesh, if foreign aid increases by $1 \%$ then the GDP growth, gross capital formation, and education rate will accelerate to $0.1988 \%, 0.6015 \%$, and $0.0652 \%$ respectively. So it is evident that foreign aid plays a propitious role to progress the economic growth of Bangladesh. It is a crying need to swell up effectiveness, transparency, proper accountability in allocation, and stronger management of aid inflows to speed up economic growth.
\end{abstract}

Keywords: Foreign Aid, GDP Growth, OLS Methods, Bangladesh.

JEL Classification Codes: F2, I2, O4. 


\section{INTRODUCTION}

Having independence in 1971 Bangladesh, a poorest and mostly densely populated country, is facing multiplex challenges with extensive corruption, acute poverty, educational barriers and poor healthcare facilities. In addition to constant natural calamities intensify the severity that crying need of foreign aid in the development of many sectors. Basically Aid is for uplifting the people around 64 million living here who are lying under the international poverty line at $\$ 1.25$ per day, dropping poverty rate by $19 \%$ both for rural and urban areas for last few decades. The poverty headcount ratio is $\$ 1.90$ per day was at $24.5 \%$ in 2005 go down to $18.5 \%$ in 2010 (Chowdhury, 2018). The World Bank reported that the economy of Bangladesh is growing up at nearly $6 \%$ per year over the past decades. Aid from the International Development Association (IDA) $\$ 16$ billion in 2013 supports to reform the policies as well as various investment projects in which more than $\$ 12.5$ billion had been used for the purpose of healthcare, promoting education and infrastructural development that ultimately triggering the growth. Around $\$ 40,488$ million aid has been invested to develop infrastructures and services i.e., energy, transportation, communication and financial institutions from 2001-19. On the other hand, social infrastructure and service (i.e., health and sanitation, education and water supply) got expenditure $\$ 25,710$ million. But the dependency on aid (in terms of development projects) is almost weakened closer to 2019. In the fiscal year 2001-02 around half (48\%) of the Annual Development Program (ADP) budgets was the aid funded that has been decreased to 32\% in the fiscal year 2019-20 (Rafi \& Khan, 2021).

The Official Development Assistance which is known as foreign aid plays an effective role to foster economic development and erode the poverty from the third world countries over the few centuries. The welfare of a nation could be measured in the form of how it impacts on economic growth. The World Bank and IMF are prominent to stretch their helping hand to uplift the world economic affairs. Though many years have been passed, it is still now a question for the recipient countries whether foreign aid is an effective way to lower their economic hardness and boost up the economic growth. A plenty of empirical studies tried to unveil the connection of foreign aid and economic growth in various way. But there is no uniform ground regarding the findings of the actual effectiveness of foreign aid for the recipient nations. .

Two well-known researcher Griffin and Enos (1970) had broken the capital inflows through aid, private capital and other inflows for the convenience of testing that revealed the aid coefficient is significant and positively influence the economic growth. Burnside and Dollar (2000) explored that foreign aid leads the growth in the 56 developing countries only for good policies rather than poor policies. Good policies should be incorporated with the proper management of small budget deficits, effective control over inflation and focusing on international trade, recommending that aid would extend efficiency if it had been allocated systematically over good policies. Using a large sample of 68 developing countries by Durbarry et al. (1998), confirmed that the positive interaction of aid on growth, conditioning on a stable macroeconomic policy applying the Augmented Fischer-Easterly type model. In contrast, Voivodas (1973) detected a negative correlation of aid and growth by studying 12 years' time series data of 22 Least Developed Countries from 1956-1968. The calculated aid coefficient was not also statistically significant. Analyzing the pooled data of 13 Asian countries, Dowling Jr and Hiemenz (1983) examined aid-growth nexus and concluded that a significant and positive effect, adding trade, finance and intervention of local government as a policy variables. Levy (1988) also got positive results for the Sub-Saharan African Countries during 1968-82. Ram (2004) noted an important question that is there any influence of aid on growth based on the recipient 
country's policies? Employing the Burnside-Dollar policy index with two other broader measure, he noted that good policy has no effect on aid and alleviation of poverty in developing countries. A more formal attempt by Ghura et al. (1995) to detain the probable side effect of aid, i.e., "Dutch-Disease effect" and some policy variables to economic growth with the more sophisticated model sampling 41 countries from 1986-92 found the positive results with enormous evidence. A different conclusion of Burnside and Dollar (1997) was that aid effect policy variables strongly, but the ratio of aid-GDP does not significantly influence on the economic growth in the LDCs. Mosley (1980) reported a weedy inverse relation on aid-growth nexus developing a simultaneous equation model, but he got positive and significant statistical results from the poorest countries' sample. The test results of Boone (1996) reported that foreign aid has no effect on the investment growth as well as income to uplift the poor one rather than make healthier the political elites because they are receiving benefits continuously irrespective of liberal democratic, or highly repressive, suggesting the effectiveness of a short term aid targeted the program for LDCs. After having a wider sample of 120 countries, Lohani (2004) unveiled the relationship between foreign aid and development. Incorporating knowledge index, heath index and standard of living index for measuring development, this paper captured a negative link of aid-growth prescribing that the government should emphasize largely on foreign direct investment and domestic investment to boost up growth. Moreira (2005) addressed foreign aid enhances growth in the developing countries analyzing macroeconomic data for 48 developing countries from 1970-98 arguing the importance of time lags effective in short-run rather than long-run. Chheange (2009) documented aid triggers corruption rather than growth, even using panel data sampling 67 developing countries from 1986 to 2005 suggesting two lessons: avoid aid or utilize it for good governance by the recipient countries. Analyzing cross country data, Knack (2001) noted foreign aid corrodes the institutional quality of the public sector stimulating rent seeking behavior and corruption. Heavy aid dependency impedes good governance through raising bureaucratic complexity and misusing laws. Tait et al. (2015) studied aid-growth nexus on 25 Sub-Saharan African countries during 1970-2012. By testing the fixed effect model, they showed aid, in the form of grant, extend the economic growth positively only in the long run. Sahoo (2016) uncovered similar results studying the South Asian countries, especially for SriLanka, India and Pakistan applying co-integration test and vector error correction model. By contrast, Fatima (2014) cast doubt to link up the issues for Pakistan both in aggregate and disaggregate level.

The above studies indicate that the aid-growth relationship is yet inconclusive that should welcome us to continue further research.

\section{OBJECTIVES OF THE RESEARCH}

- To identify the relationship of GDP growth and foreign aid.

- To verify the effect of gross capital formation (GCF), population (POP) and education (EDU) on GDP of Bangladesh.

- To recommend some policies for ODA, GCF. POP and EDU to strengthen economic growth.

\section{DATA AND METHODOLOGY}

In this empirical study, the causality of foreign aid and economic growth in Bangladesh is examined by the econometric model in which Gross Domestic Product (GDP) is dependent variables against the other independent variables i.e., Foreign Aid (ODA), Gross Capital 
Formation (GCF), Population (POP) and Education (EDU). The econometric models (i.e., Unit root tests and Ordinary Least Square (OLS) Method) have been applied for processing variables. Annual time series data from 1971 to 2019 was collected from the website of World Bank. The econometric equation has been built to the hypotheses in this study is as follows:

$$
\mathrm{GDP}=\alpha+\beta_{1} \mathrm{ODA}+\beta_{2} \mathrm{GCF}+\beta_{3} \mathrm{POP}+\beta_{4} \mathrm{EDU}+\epsilon
$$

$$
\begin{aligned}
\text { Where, } & \\
\text { GDP } & =\text { Log of Gross Domestic Product } \\
\text { ODA } & =\text { Log of Foreign Aid } \\
\text { GCF } & =\text { Log of Gross Capital Formation } \\
\text { POP } & =\text { Log of Population } \\
\text { EDU } & =\text { Log of Education } \\
\alpha & =\text { Intercept } \\
\beta & =\text { Coefficient } \\
\in & =\text { Error Term }
\end{aligned}
$$

$\beta_{1}, \beta_{2}, \beta_{3}$ and $\beta_{4}$ are the coefficients of the respective variables. In this model GDP is the dependent variable while ODA, GCF, POP and EDU are considered as the independent variables.

Hypotheses are as follows:

$\mathrm{H}_{1}$ :Foreign Aid has positive relation with GDP

$\mathrm{H}_{2}$ :Gross Capital Formation has positive relation with GDP

$\mathrm{H}_{3}$ :Population has positive relation with GDP

$\mathrm{H}_{4}$ :Education has positive relation with GDP

\section{Stationary Test}

\section{EMPIRICAL RESULTS}

\section{Augmented Dickey-Fuller (ADF) Test}

The unit root test has been applied to verify the data used in the study either stationary or not. The ADF test has been used for this purpose. If the data is stationary only in that case results are more reliable, but if time series data is not stationary, then the results will no longer be valid.

Table 1 reports results of the Augmented Dickey-Fuller (ADF) test. The t-statistics are to be calculated for both intercept and, trend and intercept cases. The hypotheses are: $\mathrm{H}_{0}$ : The variables have unit root, i.e., non-stationary, $\mathrm{H}_{1}$ : The variables have no unit root, i.e., stationary. If t-statistics are greater than ADF critical values or p-values are greater than $5 \%$ level of significance, then the null hypothesis can't be rejected. That means the variables have unit root or the variables are non-stationary. On the other hand, if t-statistics are less than ADF critical values or p-values are less than 5\% level of significance, then we can reject null hypothesis. Therefore, the unit root does not exist in the variables. So the variables will be stationary. 
Table 1. Results of Augmented Dickey-Fuller (ADF) Test

\begin{tabular}{|c|c|c|c|c|}
\hline & \multicolumn{2}{|c|}{ Intercept } & \multicolumn{2}{c|}{ Trend and intercept } \\
\hline Variables & Level & First Difference & Level & First Difference \\
\hline GDP & 0.114 & $-7.333^{*}$ & -3.277 & $-7.223^{*}$ \\
\hline ODA & -2.688 & $-10.947^{*}$ & -3.502 & $-10.523^{*}$ \\
\hline GCF & -0.164 & $-5.651^{*}$ & -2.574 & $-5.462^{*}$ \\
\hline POP & -0.412 & $-4.202^{*}$ & -1.732 & $-3.411^{*}$ \\
\hline EDU & 1.038 & $-5.319^{*}$ & -0.817 & $-5.832^{*}$ \\
\hline
\end{tabular}

Note: * denotes $5 \%$ level of significance.

Here computed ADF test statistics 0.114 is for GDP at level with intercept which is less than the critical values and p-value is not significant at the 5\% level. That dictates the null hypothesis could not be rejected. So, it has the unit root problem and series are non-stationary at level. When the series turns into first difference, then the value $(-7.333)$ becomes significant at $5 \%$ level and turns into stationary. Similarly at level with trend and intercept, the test statistics 3.277 is not significant but at first difference series becomes stationary.

In the same way, the computed ADF test (at level with intercept) statistics are -2.688, $0.164,-0.412$ and 1.038 for ODA, GCF, POP and EDU respectively. All these values are insignificant at $5 \%$ level of significance. When they transformed into first difference, then all the variables become stationary. In case of the trend and intercept all the selected variables are stationary at the first difference but not level form.

\section{Phillips-Perron (PP) Test}

To testify unit root, an alternative test was suggested by Phillips in 1987 that was modified by Perron in 1988, and both Philips and Perron in 1988. Actually, it is a non-parametric statistical test that considered serial correlation of error terms without lagged difference terms. The asymptotic distribution of PP test is analogous to ADF test statistics.

Table 2. Results of Phillips-Perron Unit Root Test

\begin{tabular}{|c|c|c|c|c|}
\hline & \multicolumn{2}{|c|}{ Intercept } & Trend and intercept \\
\hline Variables & Level & First Difference & Level & First Difference \\
\hline GDP & 1.266 & $-12.993^{*}$ & -3.466 & $-12.696^{*}$ \\
\hline ODA & -6.852 & $-12.942^{*}$ & -7.871 & $-12.236^{*}$ \\
\hline GCF & 0.477 & $-11.267^{*}$ & -3.530 & $-11.446^{*}$ \\
\hline POP & -0.176 & $-3.921^{*}$ & -1.661 & $-4.441^{*}$ \\
\hline EDU & 1.190 & $-5.335^{*}$ & -0.817 & $-5.745^{*}$ \\
\hline
\end{tabular}

Note: * denotes $5 \%$ level of significance.

Table 2 represents results of Phillips-Perron tests for five variables- Gross Domestic Product (GDP), Foreign Aid (ODA), Gross Capital Formation (GCF), Population (POP) and Education (EDU) in logarithmic form. The hypotheses are: $\mathrm{H}_{0}$ : The variables have unit root, i.e., non-stationary, $\mathrm{H}_{1}$ : The variables have no unit root, i.e., stationary. If t-statistics are greater than PP critical values, then we can't reject null hypothesis. That mean the variables have unit root or 
the variables are non-stationary. If t-statistics are less than PP critical values or p-values are less than 5\% level of significance, then we can reject null hypothesis. So the variables become stationary. Computed PP test statistics are not statistically significant for all variables at level irrespective of both cases i.e., intercept or trend and intercept. The variables contained unit root at level form, but when they are transformed into the first difference then they become stationary.

\section{Regression Model}

Table 3 represents the results of multiple regression analysis. It has been seen that the $\mathrm{R}^{2}$ value 0.997110 indicates that there is more than $99 \%$ variation of the dependent variable is caused by independent variables. Again the p-values for the most of the variables are less than 5\% that indicates the coefficients are statistically significant. In addition, the F-statistic 2587.646 is also significant at 5\% significance level. All these characteristics indicate that the econometric model is fitted well. Using the value of the coefficients, the econometric model could be expressed as follows:

$$
\begin{aligned}
\mathrm{D}(\mathrm{GDP})=6.514123+0.198894 \mathrm{D}(\mathrm{ODA})+0.601543 \mathrm{D}(\mathrm{GCF})-0.279842 \mathrm{D}(\mathrm{POP}) \\
+0.065203 \mathrm{D}(\mathrm{EDU})
\end{aligned}
$$

The regression results indicate that GDP is positively related with ODA, GCF and EDU, but negatively related to POP. If foreign aid increases by $1 \%$ then the GDP growth will accelerate to $0.1988 \%$ in Bangladesh. In the same way, a $1 \%$ addition to gross capital formation and education rate will lead to change GDP growth by $0.6015 \%$ and $0.0652 \%$ respectively. In contrast, if the number of population increases to $1 \%$, it will negatively affect the GDP growth by $0.2798 \%$ in Bangladesh.

\begin{tabular}{|c|c|c|c|c|}
\hline \multicolumn{5}{|c|}{ Dependent Variable: D(GDP) } \\
\hline Variable & Coefficient & Std. Error & t-Statistic & Prob. \\
\hline $\mathrm{D}(\mathrm{ODA})$ & 0.198894 & 0.044388 & 4.480824 & 0.0001 \\
\hline $\mathrm{D}(\mathrm{GCF})$ & 0.601543 & 0.040328 & 14.91636 & 0.0000 \\
\hline $\mathrm{D}(\mathrm{POP})$ & -0.279842 & 0.055341 & -5.056703 & 0.0000 \\
\hline $\mathrm{D}(\mathrm{EDU})$ & 0.065203 & 0.081217 & 0.802820 & 0.4284 \\
\hline $\mathrm{C}$ & 6.514123 & 0.510187 & 12.76810 & 0.0000 \\
\hline R-squared & 0.997110 & \multicolumn{2}{|c|}{ Mean dependent var. } & 24.65915 \\
\hline Adjusted R-squared & 0.996725 & \multicolumn{2}{|c|}{ S.D. dependent var. } & 1.008611 \\
\hline S.E. of regression & 0.057723 & \multicolumn{2}{|c|}{ Akaike info criterion } & -2.734743 \\
\hline Sum squared resid. & 0.099960 & \multicolumn{2}{|c|}{ Schwarz criterion } & -2.512550 \\
\hline Log likelihood & 52.85800 & \multicolumn{2}{|c|}{ Hannan-Quinn criter. } & -2.658042 \\
\hline F-statistic & 2587.646 & \multicolumn{2}{|c|}{ Durbin-Watson stat } & 1.270732 \\
\hline Prob(F-statistic) & 0.000000 & & & \\
\hline
\end{tabular}

Table 3. The Results of Regression Analysis 


\section{Diagnostic Tests \\ Normality Test}

From the Figure 1 it is to be seen that the probability value of Jarque-Bara statistic is larger than $5 \%$ which is 0.6057 . So the null hypothesis of residuals follows normal distribution could be accepted. Therefore, residuals of this model follow normal distribution.

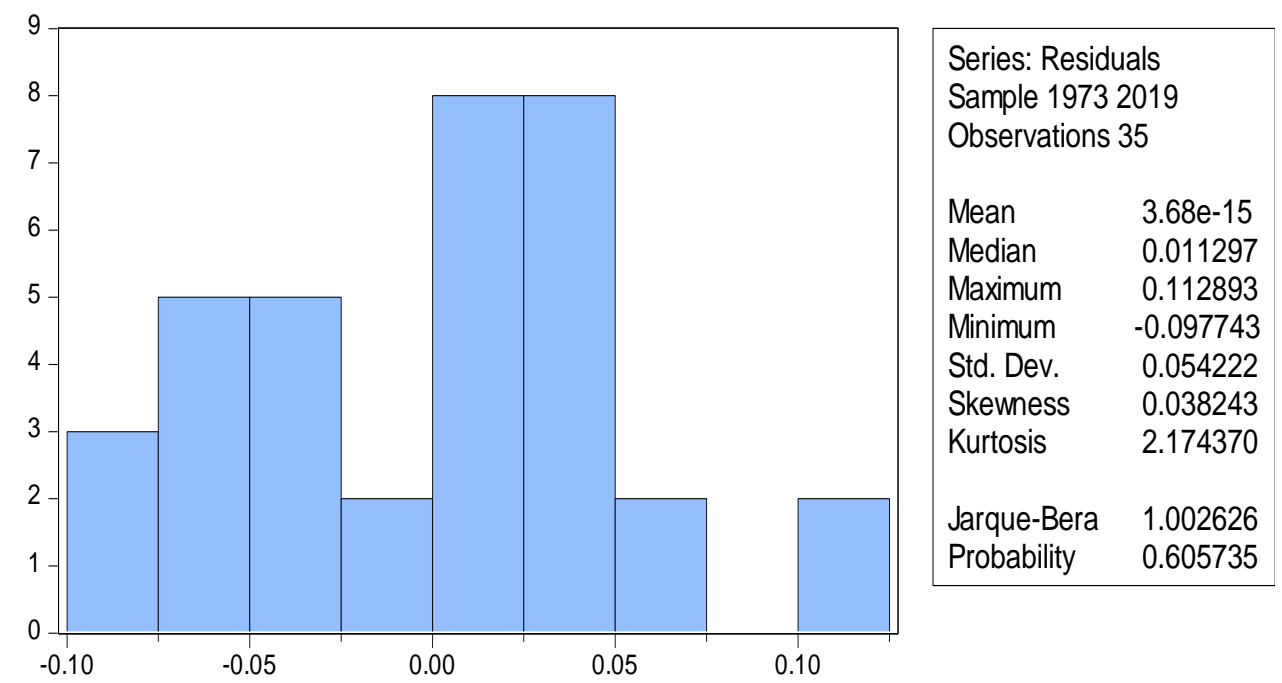

Figure 1. Histogram normality test

\section{Serial Correlation Test}

Table 4 reported the results of Breusch-Godfrey serial correlation LM test. The observed Rsquared value is 1.381875 and $\mathrm{p}$-value of Chi-Square 0.5011 is greater than $5 \%$, indicating that there is no serial correlation.

Table 4. Breusch-Godfrey serial correlation LM Test

\begin{tabular}{|l|r|l|r|}
\hline F-statistic & 0.575471 & Prob. F(2,28) & 0.5690 \\
\hline Obs*R-squared & 1.381875 & Prob. Chi-Square(2) & 0.5011 \\
\hline
\end{tabular}

\section{Heteroskedasticity Test}

Table 5 reported results of the Breusch-Pagan-Godfrey heteroskedasticity test. It can be noted that the observed R-squared value is 3.351028 and p-value is $0.5009>0.05$ indicating the residuals have no heteroskedasticity problem.

Table 5. Heteroskedasticity Test: Breusch-Pagan-Godfrey

\begin{tabular}{|l|l|l|r|}
\hline F-statistic & 0.794108 & Prob. F(4,30) & 0.5384 \\
\hline Obs*R-squared & 3.351028 & Prob. Chi-Square(4) & 0.5009 \\
\hline Scaled explained SS & 1.445637 & Prob. Chi-Square(4) & 0.8362 \\
\hline
\end{tabular}




\section{Stability Test}

To test out the stability of our model it is better to perform the cumulative sum of recursive residual (CUSUM) test. Following the Figure 2 it has been seen that the recursive error falls between the two critical lines that indicate the estimated model and parameters are stable during the sample period in our study.

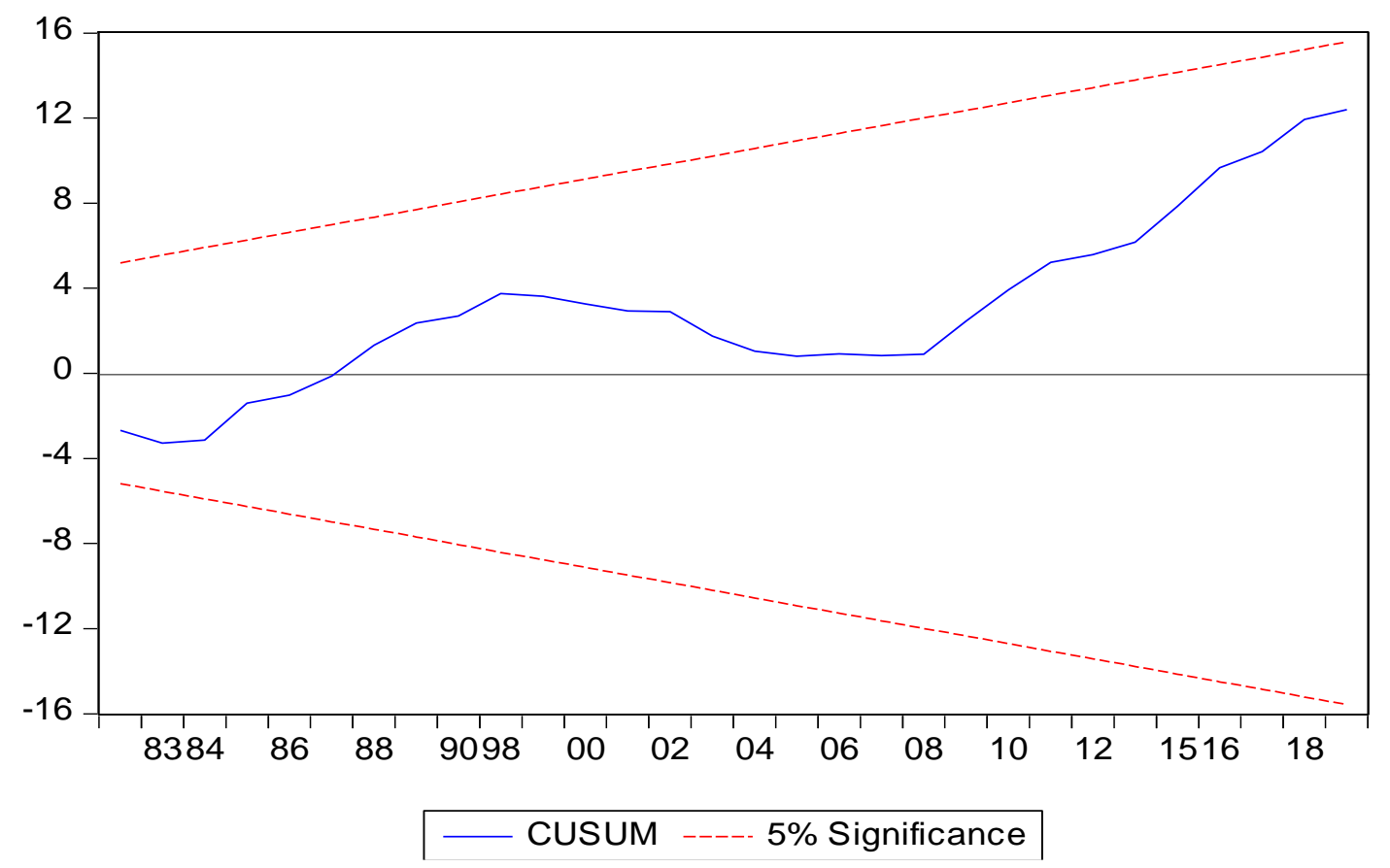

Figure 2. The Plot of CUSUM test

\section{CONCLUDING REMARKS AND RECOMMENDATIONS}

The study explores the linkage of foreign aid and economic growth in Bangladesh using OLS method. Specifically, it attempts to find out whether the aid and growth are positively or negatively related. Both ADF and PP tests have been employed to verify the pattern of time series data either stationary or not. Data for all the variables i.e., Gross Domestic Product (GDP), Foreign Aid (ODA), Gross Capital Formation (GCF), Population (POP) and Education (EDU) are not stationary at level. After transforming into the first difference they changed into stationary which is a precondition of regression analysis. The regression model is fitted well passing normality, serial correlation, heteroskedasticity and stability tests and confirmed that GDP growth has positive association with foreign aid, gross capital formation and education, but negative association with the population. It is to be noted that a $1 \%$ increment in aid promotes the economic growth around $0.1988 \%$ based on sampling data. However, the study is suggesting that Government should focus on the proper allocation of aid funding through transparent and effective management. Additionally, an aid effectiveness program launched by UNDP could be strictly followed. However, how the foreign aid impacts in the development of specific sector could be a key concern for further research. 


\section{AUTHOR CONTRIBUTIONS}

Conceptualization: Shahadat Hussain, Md. Habibur Rahman

Data Curation: Shahadat Hussain, Md. Habibur Rahman

Formal Analysis: Shahadat Hussain, Md. Habibur Rahman

Funding Acquisition: Shahadat Hussain, Md. Habibur Rahman

Investigation: Shahadat Hussain, Md. Habibur Rahman

Methodology: Shahadat Hussain

Project Administration: Shahadat Hussain

Resources: Shahadat Hussain, Md. Habibur Rahman

Software: Shahadat Hussain

Supervision: Shahadat Hussain

Validation: Shahadat Hussain, Md. Habibur Rahman

Visualization: Shahadat Hussain, Md. Habibur Rahman

Writing - Original Draft: Shahadat Hussain

Writing - Review \& Editing: Shahadat Hussain, Md. Habibur Rahman

\section{CONFLICT OF INTEREST STATEMENT}

The authors declare that they have no competing interests.

\section{ACKNOWLEDGEMENT}

All authors contributed equally to the conception and design of the study.

\section{REFERENCES}

Boone, P. (1996). Politics and the effectiveness of foreign aid. European economic review, 40(2), 289-329. https://doi.org/10.1016/0014-2921(95)00127-1

Burnside, C., \& Dollar, D. (1997). Aid spurs growth-in a sound policy environment. Finance \& Development, 34(004).

Burnside, C., \& Dollar, D. (2000). Aid, policies, and growth. American economic review, 90(4), 847-868. https://doi.org/10.1257/aer.90.4.847

Chheang, V. (2009). The effect of foreign aid on economic growth and corruption in 67 developing countries. Georgetown University.

Chowdhury, M. (2018, February 17). The Effectiveness of Foreign Aid in Bangladesh. Borgen Magazine. Retrieved from https://www.borgenmagazine.com/effectivenessof-foreign-aid-in bangladesh/\#: :text=Foreign\%20aid\%20in\%20Bangladesh\%20is\%20primarily\%20us ed\%20to,measured\%20in\%20terms\%20of\%20improvement $\% 20$ of\%20this $\% 20$ issue.

Dowling Jr, J. M., \& Hiemenz, U. (1983). Aid, savings, and growth in the Asian region. The Developing Economies, 21(1), 3-13. https://doi.org/10.1111/j.1746-1049.1983.tb00641.x 
Durbarry, R., Gemmell, N., \& Greenaway, D. (1998). New evidence on the impact of foreign aid on economic growth(No. 98/8). CREDIT Research paper. Retrieved from http://hdl.handle.net/10419/81776

Fatima, F. (2014). Foreign aid and economic growth. Available at SSRN 2407348. Retrieved from http://dx.doi.org/10.2139/ssrn. 2407348

Ghura, M. D., Hadjimichael, M. M. T., Mühleisen, M. M., Nord, M. R., \& Ucer, E. M. (1995). Sub-Saharan Africa: growth, savings, and investment, 1986-93 (No. 1995/006). International Monetary Fund.

Griffin, K. B., \& Enos, J. L. (1970). Foreign assistance: objectives and consequences. Economic development and cultural change, 18(3), 313-327.

Knack, S. (2001). Aid dependence and the quality of governance: cross-country empirical tests. Southern economic journal, 310-329.https://doi.org/10.1002/j.23258012.2001.tb00421.x

Levy, V. (1988). Aid and growth in Sub-Saharan Africa: The recent experience. European Economic Review, 32(9), 1777-1795. https://doi.org/10.1016/0014-2921(88)90085-2

Lohani, S. (2004). Effect of Foreign Aid on Development: Does More Money Bring More Development?. Illinois Wesleyan University: Honors Projects. Retrieved from https://digitalcommons.iwu.edu/econ_honproj/18

Moreira, S. B. (2005). Evaluating the impact of foreign aid on economic growth: A cross-country study. Journal of Economic Development,30(2), 25-48. Retrieved from http://hdl.handle.net/10400.26/4464

Mosley, P. (1980). Aid, savings and growth revisited. Oxford Bulletin of Economics and Statistics, 42(2), 79-95. https://doi.org/10.1111/j.1468-0084.1980.mp42002002.x

Rafi, K. M., \& Khan, F. H. (2021, June 14). Foreign aid to Bangladesh: A thing of the past? Light Castle Partners. Retrieved from https://www.lightcastlebd.com/insights/2021/06/evolution-of-development-assistance-tobangladesh-part-2-2001-2020/

Ram, R. (2004). Recipient country's 'policies' and the effect of foreign aid on economic growth in developing countries: additional evidence. Journal of International Development: The Journal of the Development Studies Association, 16(2), 201-211. https://doi.org/10.1002/jid.1071

Sahoo, K. (2016). Foreign aid and economic development: Empirical evidence from select South Asian Economies (Doctoral dissertation). 
Tait, L., MA, B. S., \& Chatterjee, I. (2015). Foreign aid and economic growth in Sub-Saharan Africa. Australia: University of Western Australia, Business School, Economics.

Voivodas, C. S. (1973). Exports, foreign capital inflow and economic growth. Journal of international Economics, 3(4), 337-349. https://doi.org/10.1016/0022-1996(73)90026-3

\section{Copyrights}

Copyright for this article is retained by the author(s), with first publication rights granted to the journal. This is an open-access article distributed under the terms and conditions of the Creative Commons Attribution license (https://creativecommons.org/licenses/by/4.0). 